\title{
The Impact of Cocreation on the Student Satisfaction: Analysis through Structural Equation Modeling
}

\author{
Odette Pantoja Díaz, ${ }^{1,2}$ Gabriela Ribes-Giner, ${ }^{1}$ and María Rosario Perello-Marin ${ }^{1}$ \\ ${ }^{1}$ Facultad de Administración y Dirección de Empresas, Universidad Politécnica de Valencia, Camino de Vera, \\ $s / n, 46022$ Valencia, Spain \\ ${ }^{2}$ Facultad de Ciencias Administrativas, Escuela Politécnica Nacional, Ladrón de Guevara E11-253, 170517 Quito, Ecuador \\ Correspondence should be addressed to Odette Pantoja Díaz; odettepantoja1980@gmail.com
}

Received 12 May 2016; Accepted 2 November 2016

Academic Editor: Ivan Ivanov

Copyright ( 2016 Odette Pantoja Díaz et al. This is an open access article distributed under the Creative Commons Attribution License, which permits unrestricted use, distribution, and reproduction in any medium, provided the original work is properly cited.

\begin{abstract}
The objective of this study is to apply the cocreation initiative as a marketing tool in the context of university undergraduate programs. Considering that cocreation is a practice that involves stakeholders in different phases of product production or service, this research analyzes the interactions between some of the factors during the cocreation process as students collaborate with the university. These factors are participation, communication, cocreation, and satisfaction, and this study focuses on how they fuse together at the moment of cocreation. After a literature review, which supplied the basis for creating a model, we used exploratory and confirmatory factor analysis and structural equation modeling to validate the hypothesized relations between the variables; finally, the proposed cocreation model was verified. The results could empower academic institutions to develop managerial strategies in order to increase students' collaboration and satisfaction.
\end{abstract}

\section{Cocreation and the University}

Higher education has been involved in recent trends such as the increasing competition in the university market, budget reductions, the internalization of education, the growth of quality standards, and clients (students) becoming more demanding and competitive in the recruitment market. Facing this situation, universities need to reevaluate their strategies and gain a marketing orientation $[1,2]$ in order to avoid the intense competitive force [3].

Higher education institutions generate alternatives to increase their loyalty rates through active interaction with the student. Considering that consumer satisfaction positively affects loyalty [4], a strategic goal for universities is to enhance student satisfaction.

At the current research, cocreation is conducted as a marketing alternative to increase the institutions' service satisfaction at the educational level. Cocreation assures interactions and connections among different stakeholders, generating communications and collaborative ties among them [5]. This approach allows the companies to generate value through client participation, with an active role during the service process or product production [6] assuring a competitive advantage in the market [7].

Although the university world differs considerably from the business sector, academic institutions are looking to increase their service quality and stakeholder satisfaction in order to gain a competitive advantage in the current situation [8]. Thus cocreation is analyzed with the objective to research the impact of students' inclusion in activities such as curriculum and program development and the teachinglearning process. The importation of cocreation to higher education institutions allows universities to adopt a marketing orientation to seek excellence and recognize quality levels.

The purpose of this investigation is to fill the existing gap in the academic market and to determine whether it is plausible to apply cocreation at higher education institutions. This viability is explored in terms of the impact of the two principal factors (participation and communication) on the cocreation process and the impact of cocreation on student satisfaction. Researching the links among those elements will permit us to confirm whether cocreation is 
applicable in this sector. The principal research questions are do communication and student participation have a positive impact under cocreation in the university context? What are the consequences of applying cocreation in higher education institutions? Does student satisfaction increase due to the cocreation experience?

Although studies by $[9,10]$ have researched cocreation at the university level, they have only focused on postgraduate programs. The current investigation aims to respond to the aforementioned research questions by analyzing the relationships between four principal constructs (participation, communication, cocreation, and satisfaction) in undergraduate programs as the target. Through the study of these relationships, it is possible to validate the proposed model, which has cocreation as its cornerstone. The principal qualitative tools of exploratory and confirmatory factor analysis and structural equation modeling (SEM) were used to confirm or reject the different hypotheses and to validate the proposed cocreation model. The research was developed by examining a case study of undergraduate students from 11 Ecuadorian universities.

\section{Relationships between Communication, Participation, Cocreation, and Satisfaction}

In this section, the theoretical basis of the proposed cocreation model will be analyzed. Four principal constructs were identified (participation, communication, cocreation, and satisfaction), which have been detailed below by comparing the conceptual relationships existing among them at the university level.

2.1. Communication versus Participation. Communication and participation are two elements that have important impacts on cocreation when applied to the business world. Reference [11] commented about the positive effect of communication on cooperation between stakeholders. Communication with customers allows for positive client participation in open innovation processes [12], and the Internet allows broad communication with a higher userparticipation rate [13].

In their research, [14] revealed that communication technologies have a positive influence on the interaction process, allowing the generation of new products. Terblanche [15] reflected on the employer's role as an important generator in the communications process.

We find that the direct link between these two elements is maintained in the educational environment. To strengthen the relationship between university and student, it is actually a necessity to consolidate value through cocreation. Through the communication, dialogue, and participation of the involved stakeholders, it is possible to develop strategies such as knowledge cocreation in this field [16].

Authors in [17] have commented on the application to universities of methodologies such as blended learning, which integrates the traditional face-to-face system with online courses. The online learning approach, supported by the Internet and solid communication with students, guarantees quality and effective education. In this sense, the cocreation concept comes to life because the student plays an important role when he collaborates actively in the teachinglearning process.

On the other hand, student participation in formal and informal education on campus not only contributes to education quality but also positively affects the key competencies that students acquire [18]. Junco [19, p.168] described the effect of participation in social media such as Facebook, where it has been demonstrated that students' active roles are "related to out-of-class engagement."

Regarding the relationship between communication and participation, we hypothesize the following:

H1: communication has a direct, positive impact on participation.

2.2. Participation versus Cocreation. At the market and university context, participation refers to the client's collaboration with the institution, which is important in order to develop a solid exchange of information to know the consumer's (students) desires and ideas and to avoid misunderstandings and ambiguous situations [20].

The user's involvement in different steps of the processes allows the coproduction development [21], leading customers to become partial employees [22]. Several studies (e.g., [23-29]) had been analyzing the interrelationship between participation and cocreation and found an interesting result that supported the link between these two constructs at several industries.

The ties existing between participation and cocreation in the university context have been addressed in some studies. For example, students' behavior is predominantly active in what is called Education 3.0, in which collaboration allows them to gain a "strong sense of ownership of own education, cocreation of resources and opportunities" [30, p. 2]. In this standard the main objective is the generation of a more open and free learning system. That is why one of the conditions for developing this education level is the promotion of cocreation by creating multidirectional participation involving the affected parts.

Educational services include stakeholders such as students and professors; the students are emotionally and behaviorally involved during the service consumption, playing a dynamic role during the interaction. Some the benefits of such a collaboration are the facilitation of learner control, enhancement of program adaptation, and learning flexibility [8].

Another study [31] remarked on the positive impact of student participation in the curriculum design process. Across this collaboration in the cocreation activities, the teacher becomes a facilitator of learning, giving the students more responsibility at the individual and collective levels. Student collaboration and participation in different processes during the educational exchange allow satisfactory results in "both pedagogical and business outcomes" [8, p. 36].

Yeo [32, p. 72] commented that, in the transformative view, students participate actively, improve their knowledge 
and skills, and have the "ability to think critically," so collaboration leads to cocreation of knowledge.

Based on the findings obtained by the aforementioned author, we hypothesize the following:

H2: participation has a direct, positive impact on cocreation.

2.3. Communication versus Cocreation. As [5] commented, communication had evolved from one-way to participatory conversations, principally considering the Internet as an important channel of information flow. The positive influences that communication has under cocreation have been noted.

Communication between firms and clients (students) has an important influence in the cocreation process $[33,34]$ and constitutes one of the four building blocks (dialogue) identified by [35] in the DART model (dialogue, access, risk, and transparency). This model was established to consider the blocks in an accurate application of cocreation.

Social networks are a tool used to create content, as different participants can communicate and thus cocreate knowledge. Applied to the educative framework, to assure an effective dialogue, "universities/colleges and the customer must become equal and joint problem solvers" to cocreate value [36, p. 50]. With this perspective shift, the student goes from having a passive role to becoming a live participant who can promote his or her opinion and initiatives through communication to foster the cocreation process.

As [22] commented, cocreation has been fomented by different communication media, such as blogs, e-distribution, and home videos; therefore, people in environments with greater access to communications instruments are better able to collaborate in coproduction activities. Considering that universities need to create physical and virtual spaces where students can obtain information, documents, and news as well as give their feedback or news ideas, enhancing the communication channels with the institution. If communication is a mandatory condition to implement cocreation, the institution is responsible for eliminating the existing barriers to dialogue and to create a space for facilitating a proper exchange of information. Based on the research on the relationship between communication and cocreation, we hypothesize the following:

H3: communication has a direct, positive impact on cocreation.

2.4. Cocreation versus Satisfaction. Satisfaction refers to a positive reaction in front of a state of fulfillment [37] and as [38] reflected, the cocreation benefits are as follows: cost diminution, response time and sales improvement, and the induction of higher satisfaction and enjoyment. Studies by $[8,39,40]$ support the aforementioned relationship.

At higher education institutions, satisfaction is linked with "a short term attitude which arises from the students' evaluation of the educational experience, which is subjective in nature" $[8$, p. 38]. Some valuable impacts of satisfaction

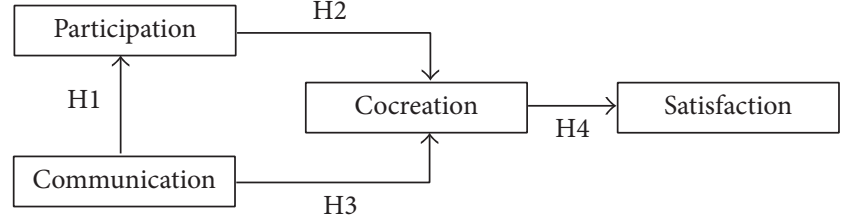

FIgURE 1: The cocreation research model.

are student loyalty, cost reduction, increase in revenue, and continued education.

In the academic context, it has been proven that when curriculum is cocreated with student collaboration, the satisfaction level increases for both teachers and students [31]. The cocreation concept empowers the university to understand what the student wants and needs, and in consequence, it is possible to deliver a superior service that directly influences student satisfaction. By tailoring its educational offers to students' needs, an institution can provide a valuable learning experience [8].

In their study, [41] reformulated Porter's value chain by coupling it to the higher education sector. The primary services/attributes they proposed were programs, regulation recognition, moment of truth, learning spirit, and service competition; the supporting services were professional recruitment, modern tools and infrastructure, library, and after-sales service. Under this proposed change, the university and the students will be able to cocreate value that satisfies both parties.

As [42, p. 728] commented, value cocreation is a learning process characterized as "emergent, unstructured, interactive, and uncertain." For that reason, the delivery of activities is important, and faculty-student and student-student interactions are key to the learning experience. The accomplishment of student expectations generates satisfaction growth, but when the institution exceeds what the client/student wants, then loyalty is reached.

On the relationship between cocreation and student satisfaction, we hypothesize the following:

H4: cocreation has a direct, positive impact on satisfaction.

2.5. The Hypothesized Cocreation Model. The model to be validated is shown in Figure 1, which reflects the different relationships to be analyzed. The different ties existing between the constructs communication, participation, cocreation, and satisfaction have theoretical support from different authors, as mentioned above. The principal objective of this model is to analyze the impact of cocreation on satisfaction in the higher education world.

The hypotheses to be studied are four and presented in Table 1; the different constructs involved in the model and the questionnaire items related to the components are also shown. 
TABLE 1: Hypothetical links in the research model, the constructs analyzed, and the related questionnaire items.

\begin{tabular}{lcc}
\hline Hypothesis & Construct & Items \\
\hline $\begin{array}{l}\text { H1: communication has a direct, } \\
\text { positive impact on participation. }\end{array}$ & Participation & $\begin{array}{c}\text { com1, com2, } \\
\text { par1, par2, } \\
\text { par3, par4 }\end{array}$ \\
\hline $\begin{array}{l}\text { H2: participation has a direct, } \\
\text { positive impact on cocreation. }\end{array}$ & Cocreation & $\begin{array}{r}\text { cocre1, cocre2, } \\
\text { cocre3, cocre4 } \\
\text { par1, par2, } \\
\text { par3, par4 }\end{array}$ \\
\hline $\begin{array}{l}\text { H3: communication has a direct, } \\
\text { positive impact on cocreation. }\end{array}$ & Cocreation & $\begin{array}{r}\text { cocre1, cocre2, } \\
\text { cocre3, cocre4 } \\
\text { com1, com2, } \\
\text { com3, com4 }\end{array}$ \\
\hline $\begin{array}{l}\text { H4: cocreation has a direct, } \\
\text { positive impact on satisfaction. }\end{array}$ & Cocreation & $\begin{array}{c}\text { cocrel, cocre2, } \\
\text { cocre3, cocre4 } \\
\text { sat1, sat2, } \\
\text { sat3 }\end{array}$ \\
\hline
\end{tabular}

\section{Methodology, Data Collection, and Technique}

The technique applied during the investigation's development to recollect information was a structured questionnaire comprising of 31 questions; only 12 questions were analyzed in the present research related to the variables studied. A Likert scale with 7-level items, from strongly disagree (1) to strongly agree (7), was applied. The questionnaire composition proceeded from previously accomplished investigations $[9,43-46]$ and was distributed in two ways, physically and electronically, in 11 public and private Ecuadorian universities. We obtained 395 responses (92 women and 303 men) among the different versions distributed in order to prevent possible bias and to randomize the question order [47]. The questionnaire was applied only in undergraduate programs, including students in their fourth through tenth semesters, considering those scholars have a solid perception about the university's services.

3.1. Measures. Our measurements were adapted from existing scales developed in other studies in order to measure the four constructs (communication, participation, cocreation, and satisfaction). Participation was adapted from a validated questionnaire created by [43] measuring the degree of the information students shared with the university and how much they were involved in the institution's process. Communication was extracted from $[44,48]$ investigations, analyzing the exchange of information among the parties involved. Cocreation's construct checked how the students were involved in the different academic and administrative processes, and it was measured by four items adapted from $[9,45,46]$. Satisfaction is comprised of items extracted from $[45,46]$ and studied the contentment that the user has with the institution. Since all questions were originally in English, they were translated to Spanish for this study.

\section{Empirical Results: Multivariate Analysis}

To analyze the results, we applied a confirmatory factor analysis to explore the associations between items and constructs and, lastly, SEM to investigate the causal relationships existing between constructs.

4.1. Exploratory Factor Analysis (EFA). EFA was applied in order to check whether the principal components detected by this technique were similar to the components identified by the authors, recognizing that items that are pooled jointly measure the same factor $[49,50]$. Every variable was included, taking into account the theoretical basis and allowing the EFA to corroborate whether those statements were correct. EFA granted the validity of each construct through the principal components method [51]. It used the SPSS v19 program, and the results showed that there are four principal components, as established in the proposed model (participation, communication, cocreation, and satisfaction).

A Varimax rotation and the maximum likelihood extraction method were used with the four fixed components. Table 2 reflects the results of the first and second iteration. In the first iteration, problems with four items were detected (par3: I have a high level of participation in the service process, coml: the information provided by the university can be trusted, com2: in case of any problem, the university provides me with enough information, and sat3: I think I did the right thing when I enrolled in this university). The items par3, com1, and com 2 had loading differences under 0.1 with several constructs. The item sat 3 had a loading difference above 0.1 , but its highest loading values do not correspond with the construct relative to satisfaction. For that reason, those four items were dropped; the rest of them (11 items) remained in the analysis.

Cronbach's alpha [52] is an indicator that reflects the homogeneity in the instrument's consistency; the second and last iteration had an excellent value of 0.906 (above 1300.7 ). The explained variance of the four principal components is about $64.4 \%$. The KMO value is 0.910 , higher than 0.5 [53], and the Bartlett test returned as $p=0.000$. The differences in these indicators between the first and the second EFA are minimal, and despite the diminished Cronbach's alpha (from 0.926 to 0.906 ) and decreased KMO (from 0.936 to 0.9910 ), both indicators had excellent values.

4.2. Confirmatory Factor Analysis. A confirmatory factor analysis (CFA) was carried out with the remaining items. In this step the SPSS Analysis of Moment Structures (AMOS) program was used, allowing us to assess the overall measurement model.

A convergent and discriminant analysis to evaluate the model's validity was used. The convergent validity was studied through the composite reliability (CR), average variance extracted (AVE), and the factor loading of each item. Table 3 shows AVE values for the four constructs, and all of them had values above 0.5 , proving that the variance captured by the constructs is larger than the variance due to measurement errors, as stated by [54]. The CR, as [55] mentioned, brings a proportion of variance attributable to only the latent variable 
TABLE 2: Exploratory factor analysis results.

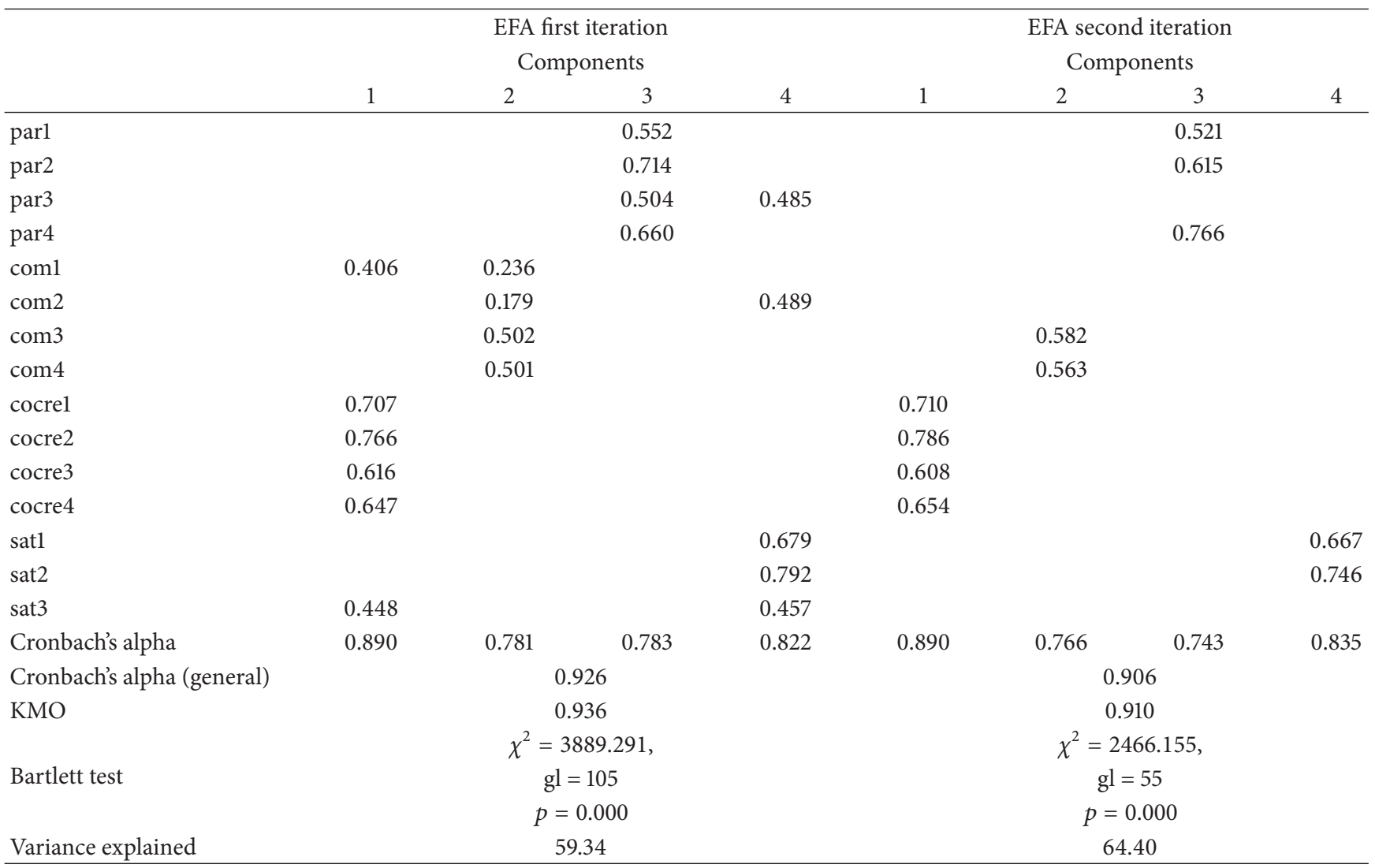

TABLE 3: Confirmatory factor analysis, CR, and AVE.

Constructs Factor loadings $\quad t$-values

Participation $(C R=0.764, A V E=0.519$, Squared Root of $A V E=0.720)$

parl I put a lot of effort into expressing my personal needs to the staff during the service process ${ }^{\mathrm{a}}$.

par2 I always provide suggestions to the staff for improving the service outcome.

0.753

0.696

par3 I have a high level of participation in the service process ${ }^{\mathrm{b}}$.

par4 I am very much involved in deciding how the services should be provided.

Communication (CR $=0.781, A V E=0.642$, Squared Root of $A V E=0.801$ )

coml The information provided by the university can be trusted ${ }^{\mathrm{b}}$.

com 2 In case of any problem, the university provides me with enough information ${ }^{\mathrm{b}}$.

com3 The university allows me to have an interactive communication with it ${ }^{\mathrm{a}}$.

-

0.711

10.157

com4 The university maintains a regular contact with me.

$-$

Cocreation $(C R=0.892, A V E=0.676$, Squared Root of $A V E=0.822)$

cocrel Overall, I would describe my relationship with this university as involving a high level of cocreation.

0.756

14.735

作

0.866

cocre3 What I receive from this university is due to work jointly between the university and student.

0.901

0.790

cocre 4 I contribute actively to the final solution in the educational service I receive.

0.721

19.829

Satisfaction $(C R=0.839, A V E=0.723$, Squared Root of $A V E=0.850)$

satl Overall, I am pleased with the services offered by this university.

0.904

17.844

sat2 The service offered by my university meets my expectations ${ }^{\mathrm{a}}$.

0.793

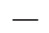

sat3 I think I did the right thing when I enrolled in this university ${ }^{\mathrm{b}}$.

Notes. CR: composite reliability. AVE: average variance extracted.

${ }^{a}$ Initial loading is fixed to 1 to set the scale of the construct.

${ }^{\mathrm{b}}$ Deleted after AFE. 
TABLE 4: Means, correlations (above diagonal), and covariance (below diagonal) among construct.

\begin{tabular}{lccccc}
\hline & Mean & Participation & Communication & Cocreation & Satisfaction \\
\hline Participation & 4.63 & 1 & 0.680 & 0.630 & 0.568 \\
Communication & 4.86 & 0.789 & 1 & 0.743 & 0.770 \\
Cocreation & 5.39 & 0.751 & 0.945 & 0.806 \\
Satisfaction & 5.27 & 0.633 & 0.916 & 0.984 & 1 \\
\hline
\end{tabular}

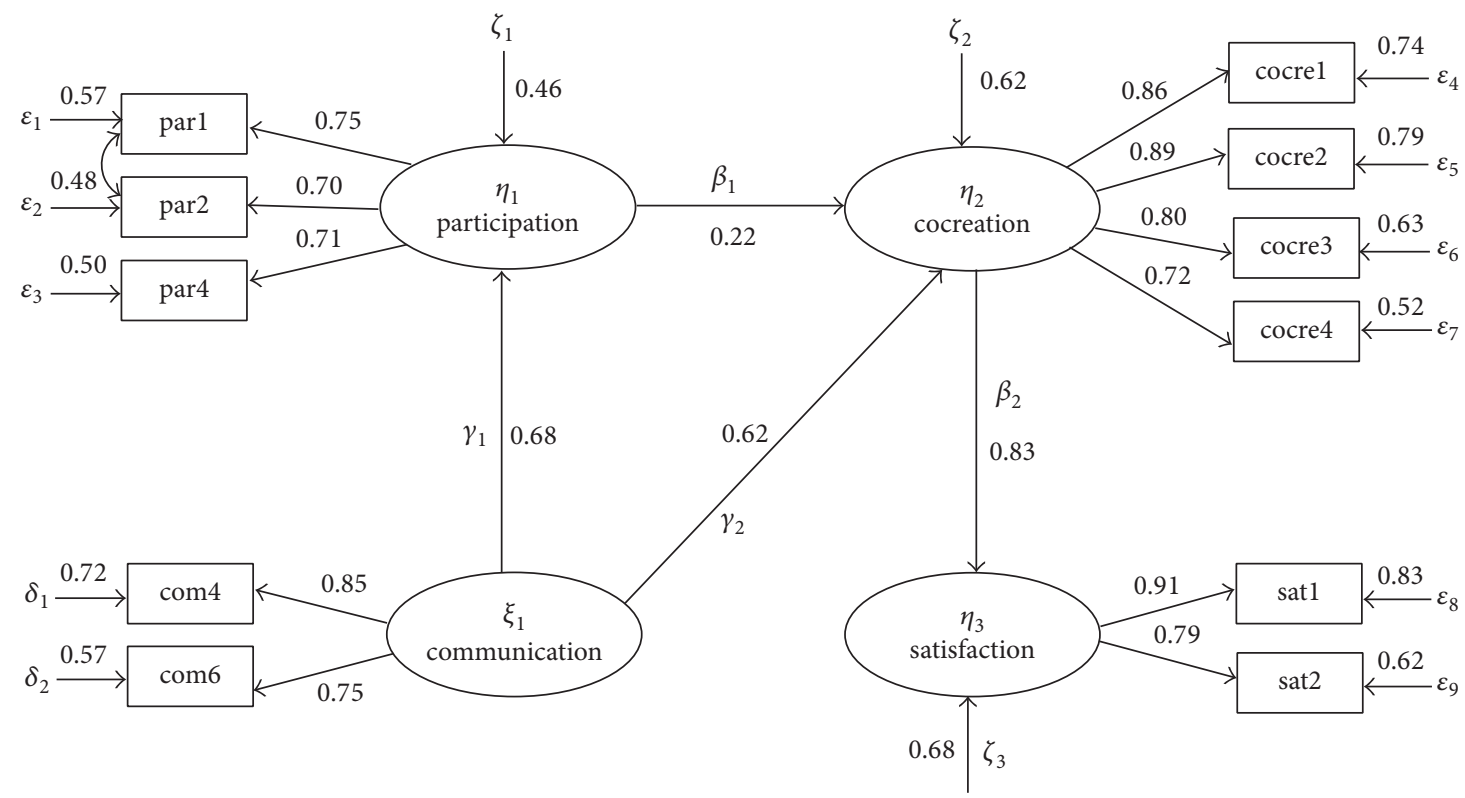

Figure 2: SEM model.

with a recommended value greater than 0.7 , putting the four constructs' $\mathrm{CR}$ values above the upper bound and confirming the model's reliability. Also, all the factor loadings are higher than 0.5 , and the estimated coefficients of each item are all significant $(t$-value $>2.0$; [21, 56]).

In looking for the discriminant validity, we noticed that the square roots of the AVEs had higher values than the correlations among the constructs. For example, cocreation and satisfaction have AVE values of 0.676 and 0.723 , the square roots of AVE are 0.822 and 0.850 , respectively, and both values are higher than the correlation between cocreation and satisfaction (0.806). The same occurred for the other constructs' relationships, assuring the discriminant validity. These analyses are shown in Tables 3 and 4.

4.3. The Structural Model. The SEM approach was used in order to validate the proposed model and to confirm the relationship between the proposed construct, with the application of the SPSS AMOS software. SEM is widely used to build and validate theories $[57,58]$. The SPSS AMOS module was used, since it was primarily created for SEM analysis.

In order to obtain a better model fit, the item errors from parl and par2 were correlated. Figure 2 shows the results of the SEM model and Table 5 shows the model fit indices and the structural model estimates.
The proposed model fits the data well. The comparative fix index (CFI) had an excellent value (0.962, over 0.95), and the adjusted goodness-of-fit index (AGFI) also had a good value $(0.903>0.8)$. The root mean square residual $(\mathrm{RMR})$ was 0.076 , under 0.09; the normative fit index (NFI) was 0.948, and the root mean square error of approximation (RMSEA) $=0.077$ (less than 0.08; [59]).

The squared multiple correlation (SMC) of cocreation showed that $62 \%(\mathrm{SMC}=0.623)$ of this element is explained by the direct effect of participation and the direct and indirect effects of communication, with a high value. Half of the variance of participation $(46 \% ; 0.459)$ was explained by the direct impact of communication; more than half of satisfaction's variance $(68 \%, 0.682)$ was explained by the direct effect of cocreation.

The four relationship studies have significant and positive impacts such as communication under cocreation with a value of $\gamma=0.62(p<0.001)$, as many authors had highlighted [21, 26-28]. Communication had a high impact on participation $(\gamma=0.68, p$ value $<0.001 ;[12,13,56])$, and participation also had a positive effect on cocreation, though with a lesser impact $(\beta=0.22, p$ value $=0.003)$, supporting the relationship established by authors like in $[5,22,60]$. Cocreation had the highest impact on satisfaction ( $\beta=0.83, p$ value $<0.001)$, as authors like in $[24,61]$ had remarked. 
TABLE 5: Structural model results. Estimates and model fit.

\begin{tabular}{|c|c|c|c|c|}
\hline & Hypothesis & Standardized coefficients $(\beta, \gamma)$ & SE & $p$ value \\
\hline \multicolumn{5}{|l|}{ Direct effects } \\
\hline Communication $\rightarrow$ participation $\left(\gamma_{1}\right)$ & $\mathrm{H} 1$ & 0.677 & 0.067 & $<0.001$ \\
\hline Participation $\rightarrow$ cocreation $\left(\beta_{1}\right)$ & $\mathrm{H} 2$ & 0.219 & 0.080 & 0.003 \\
\hline Communication $\rightarrow$ cocreation $\left(\gamma_{2}\right)$ & $\mathrm{H} 3$ & 0.625 & 0.080 & $<0.001$ \\
\hline Cocreation $\rightarrow$ satisfaction $\left(\beta_{2}\right)$ & $\mathrm{H} 4$ & 0.826 & 0.053 & $<0.001$ \\
\hline
\end{tabular}

\begin{tabular}{lc}
\hline Model fit indices & \\
CMIN/DF & $3.346 \lesssim 3$ \\
CFI & $0.962>0.95$ \\
GFI & $0.943 \gtrsim 0.95$ \\
AGFI & $0.903>0.8$ \\
RMR & $0.076<0.09$ \\
RMSEA & $0.077<0.08$
\end{tabular}

TABLE 6: Participation mediation between communication and cocreation.

\begin{tabular}{|c|c|c|c|c|}
\hline Hypothesis & $\begin{array}{c}\text { Direct effect } w / o \\
\text { mediator (1st situation) }\end{array}$ & $\begin{array}{l}\text { Direct } w \text { mediator } \\
\quad \text { (2nd sit.) }\end{array}$ & Indirect effect (3th sit.) & $\begin{array}{l}\text { Mediation type } \\
\text { observed }\end{array}$ \\
\hline $\begin{array}{l}\text { Partial mediation } \\
\text { communication, } \\
\text { participation, cocreation }\end{array}$ & $0.631^{* *}$ & $0.625^{* *}$ & $0.148^{*}$ & Partial mediation \\
\hline
\end{tabular}

${ }^{*} p$ value $<0.05 ;{ }^{* *} p$ value $<0.01$

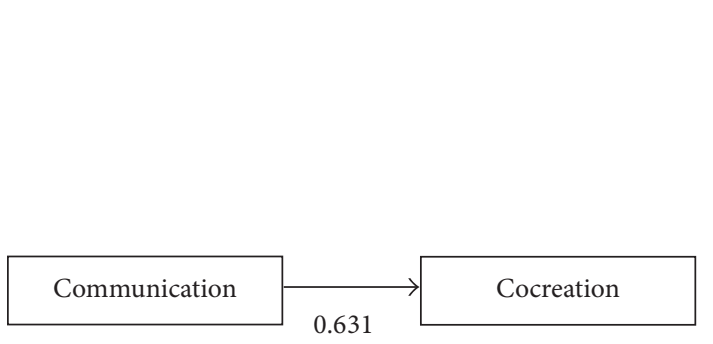

(a) Without mediator

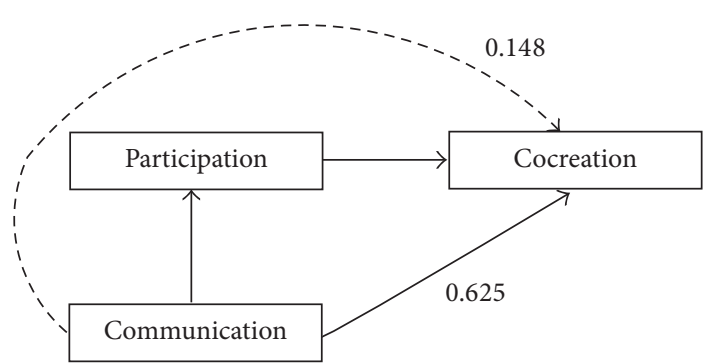

(b) With participation as a mediator

FIGURE 3: Direct effect of communication in cocreation.

We researched mediation by participation in Hypothesis $\mathrm{H} 3$, studying the relationship between communication and cocreation. Authors like in $[62,63]$ had pointed to the importance of the mediation analysis. Table 6 and Figure 3 reflect the resulting analysis, where a poor but significant partial mediation existed by participation between communication and cocreation.

The obtained results allowed us to conclude that the four hypotheses raised in the initial phase of the research are accepted. Communication had a positive and significant impact on participation (0.68), and participation had a positive and significant influence on cocreation (0.22). Communication also significantly and positively affected cocreation (0.62), and cocreation in turn affected satisfaction (0.83), with the highest regression coefficient indicating that this relationship was the strongest of all analyzed.

\section{Conclusions and Contributions}

Taking into account the principal objective of the research, the positive relationships existing between communication and participation, participation and cocreation, communication and cocreation, and lastly cocreation and satisfaction in the undergraduate context were verified. The research also validated a cocreation model, considering that participation and communication were the most important promoters of cocreation; cocreation also had a high impact on student satisfaction. This model assured the importance of a change to a management practice focused on cocreation, as was the original intent.

To face the reality of student satisfaction, higher education institutions are looking for innovative ways to improve their administration. Considering that cocreation had been 
studied previously by many authors with favorable effects in terms of satisfaction, trust, and loyalty, it is a pragmatic tool to be considered and implemented in the university context. It will be important to notice that the lowest detected interaction was between participation and cocreation. Based on this, undergraduate students mostly valued communication as a cocreation precursor. At this point, universities need to develop open dialogues and bidirectional conversations with students to enhance open talks and forums and to improve the communication channels based on information or virtual systems, Internet, or other portals where the scholar can interact with the school.

Despite satisfaction as a valuable factor in terms of competitive advantage, its existence is essential to obtain high loyalty levels. That is why it would be interesting and innovative to investigate loyalty inclusion as a new construct within the cocreation model aforementioned in further studies. Despite these relationships having been analyzed previously in postgraduate programs, they had never been researched in undergraduate programs.

It will be useful and timely to deepen our understanding of how we must change the institution's process or how to move from the actual vision of rigid value chains to newer ones, with the objective of materializing and concretely practicing the cocreation approach. The benefits of strategic management oriented to this trend have been tested, but the implementation and the actions to be undertaken are a poorly explored field.

It is important to foment and explore methodologies for applying strategies such as cocreation in the university context in order to increase the level of retention, word of mouth, and student loyalty.

\section{Competing Interests}

The authors declare that they have no competing interests.

\section{References}

[1] C. Kerr, "A critical age in the university world: accumulated heritage versus modern imperatives," European Journal of Education, vol. 22, no. 2, pp. 183-193, 1987.

[2] L. Nicolescu, "Applying marketing to higher education: scope and limits," Management \& Marketing, vol. 4, no. 2, pp. 35-44, 2009.

[3] D. B. Arnett, C. M. Wittmann, and B. J. Wilson III, "Encouraging future helping behaviors: the role of student-faculty relationships in higher education marketing," Journal of Marketing for Higher Education, vol. 13, pp. 127-157, 2004.

[4] S. W. Carvalho and M. de Oliveira Mota, "The role of trust in creating value and student loyalty in relational exchanges between higher education institutions and their students," Journal of Marketing for Higher Education, vol. 20, no. 1, pp. 145$165,2010$.

[5] A. M. Muñiz and H. J. Schau, "How to inspire value-laden collaborative consumer-generated content," Business Horizons, vol. 54, no. 3, pp. 209-217, 2011.

[6] M. Díaz-Méndez and E. Gummesson, "Value co-creation and university teaching quality: consequences for the European
Higher Education Area (EHEA)," Journal of Service Management, vol. 23, no. 4, pp. 571-592, 2012.

[7] L. A. Bettencourt, S. W. Brown, and N. J. Sirianni, "The secret to true service innovation," Business Horizons, vol. 56, no. 1, pp. 13-22, 2013.

[8] J. L.-H. Bowden and S. D’Alessandro, "Co-creating value in higher education: the role of interactive classroom response technologies," Asian Social Science, vol. 7, no. 11, pp. 35-49, 2011.

[9] G. R. Giner and A. Peralt Rillo, "Structural equation modeling of co-creation and its influence on the student's satisfaction and loyalty towards university," Journal of Computational and Applied Mathematics, vol. 291, pp. 257-263, 2016.

[10] G. Ribes-Giner, A. Peralt Rillo, and I. Moya Clemente, "Cocreation innovation model for masters programs in the universities," in Innovation and Teaching Technologies, vol. 117, 2014.

[11] J. C. Anderson and J. A. Narus, "A model of distributor firm and manufacturer firm working partnerships," The Journal of Marketing, vol. 54, no. 1, pp. 42-58, 1990.

[12] A. Vaisnore and M. Petraite, “The enablement of customer's participation in the open innovation processes: an analytical framework," Economics and Management, vol. 17, no. 4, pp. 1600-1612, 2012.

[13] R. F. Lusch and S. L. Vargo, "Service-dominant logic: reactions, reflections and rezinements," Marketing Theory, vol. 6, pp. 281288, 2006.

[14] T. Kohler, K. Matzler, and J. Füller, "Avatar-based innovation: using virtual worlds for real-world innovation," Technovation, vol. 29, no. 6-7, pp. 395-407, 2009.

[15] N. S. Terblanche, "Some theoretical perspectives of co-creation and co-production of value by customers: original research," Acta Commercii, vol. 14, no. 2, pp. 1-8, 2014.

[16] F. Pucciarelli and A. Kaplan, "Competition and strategy in higher education: managing complexity and uncertainty," Business Horizons, vol. 59, no. 3, pp. 311-320, 2016.

[17] D. R. Garrison and H. Kanuka, "Blended learning: uncovering its transformative potential in higher education," The Internet and Higher Education, vol. 7, no. 2, pp. 95-105, 2004.

[18] M. Barth, J. Godemann, M. Rieckmann, and U. Stoltenberg, "Developing key competencies for sustainable development in higher education," International Journal of Sustainability in Higher Education, vol. 8, no. 4, pp. 416-430, 2007.

[19] R. Junco, "The relationship between frequency of Facebook use, participation in Facebook activities, and student engagement," Computers and Education, vol. 58, no. 1, pp. 162-171, 2012.

[20] E. N. Rodina and E. N. Chekushkina, "Socio-philosophical substantiation of making good use of intellectual and creative resources in a teachers' training institution of higher education," Asian Social Science, vol. 11, no. 6, pp. 111-117, 2015.

[21] S. Auh, S. J. Bell, C. S. McLeod, and E. Shih, "Co-production and customer loyalty in financial services," Journal of Retailing, vol. 83, no. 3, pp. 359-370, 2007.

[22] M. Etgar, "A descriptive model of the consumer co-production process," Journal of the Academy of Marketing Science, vol. 36, no. 1, pp. 97-108, 2008.

[23] A. Ordanini and P. Pasini, "Service co-production and value co-creation: the case for a service-oriented architecture (SOA)," European Management Journal, vol. 26, no. 5, pp. 289-297, 2008.

[24] V. Ramaswamy and F. Gouillart, "Building the co-creative enterprise," Harvard Business Review, vol. 88, no. 10, pp. 100$109,2010$. 
[25] Y. Yi and T. Gong, "Customer value co-creation behavior: scale development and validation," Journal of Business Research, vol. 66, no. 9, pp. 1279-1284, 2013.

[26] A. Gustafsson, P. Kristensson, and L. Witell, "Customer cocreation in service innovation: a matter of communication?" Journal of Service Management, vol. 23, no. 3, pp. 311-327, 2012.

[27] A. F. Payne, K. Storbacka, and P. Frow, "Managing the cocreation of value," Journal of the Academy of Marketing Science, vol. 36, no. 1, pp. 83-96, 2008.

[28] K. E. Gruner and C. Homburg, "Does customer interaction enhance new product success?" Journal of Business Research, vol. 49, no. 1, pp. 1-14, 2000.

[29] S. Timmis, "Constant companions: instant messaging conversations as sustainable supportive study structures amongst undergraduate peers," Computers and Education, vol. 59, no. 1, pp. 3-18, 2012.

[30] D. Keats and J. P. Schmidt, "The genesis and emergence of Education 3.0 in higher education and its potential for Africa," First Monday, vol. 12, no. 3, 2007.

[31] C. Bovill, "An investigation of co-created curricula within higher education in the UK, Ireland and the USA," Innovations in Education and Teaching International, vol. 51, no. 1, pp. 15-25, 2014.

[32] R. K. Yeo, "Service quality ideals in a competitive tertiary environment," International Journal of Educational Research, vol. 48, no. 1, pp. 62-76, 2009.

[33] C. K. Prahalad and V. Ramaswamy, "Co-creation experiences: the next practice in value creation," Journal of Interactive Marketing, vol. 18, no. 3, pp. 5-14, 2004.

[34] A. Lundkvist and A. Yakhlef, "Customer involvement in new service development: a conversational approach," Managing Service Quality, vol. 14, no. 2-3, pp. 249-257, 2004.

[35] C. Prahalad and V. Ramaswamy, "Co-creating unique value with customers," Strategy \& Leadership, vol. 32, no. 3, pp. 4-9, 2004.

[36] A. Fagerstrøm and G. Ghinea, "Co-creation of value in higher education: using social network marketing in the recruitment of students," Journal of Higher Education Policy and Management, vol. 35, no. 1, pp. 45-53, 2013.

[37] M.-K. Kim, M.-C. Park, and D.-H. Jeong, "The effects of customer satisfaction and switching barrier on customer loyalty in Korean mobile telecommunication services," Telecommunications Policy, vol. 28, no. 2, pp. 145-159, 2004.

[38] C. K. Prahalad and V. Ramaswamy, The Future of Competition: Co-Creating Unique Value with Customers, Harvard Business Press, 2013.

[39] U. S. Grissemann and N. E. Stokburger-Sauer, "Customer co-creation of travel services: the role of company support and customer satisfaction with the co-creation performance," Tourism Management, vol. 33, no. 6, pp. 1483-1492, 2012.

[40] C. Grönroos, "Service logic revisited: who creates value? And who co-creates?" European Business Review, vol. 20, no. 4, pp. 298-314, 2008.

[41] D. Makkar, E. O. Gabriel, and D. Tripathi, "Value chain for higher education sector-case studies of India and Tanzania," Journal of Services Research, 2008.

[42] M. Pinar, P. Trapp, T. Girard, and T. E. Boyt, "Utilizing the brand ecosystem framework in designing branding strategies for higher education," International Journal of Educational Management, vol. 25, no. 7, pp. 724-739, 2011.

[43] K. W. Chan, C. K. Yim, and S. S. K. Lam, "Is customer participation in value creation a double-edged sword? Evidence from professional financial services across cultures," Journal of Marketing, vol. 74, no. 3, pp. 48-64, 2010.

[44] Z. Tohidinia and M. Haghighi, "Predictors and outcomes of relationship quality: a guide for customer-oriented strategies," Business Strategy Series, vol. 12, no. 5, pp. 242-256, 2011.

[45] E. R. Devasirvatham, Modelling co-creation and its consequences: one step closer to customer-centric marketing [Ph.D. thesis], Auckland University of Technology, Auckland, New Zealand, 2012.

[46] E. Rajah, R. Marshall, and I. Nam, "Relationship glue: customers and marketers co-creating a purchase experience," Advances in Consumer Research, vol. 35, pp. 367-373, 2008.

[47] B. C. K. Choi and A. W. P. Pak, "A catalog of biases in questionnaires," Preventing chronic disease, vol. 2, no. 1, p. A13, 2005.

[48] P. Harrigan and M. Miles, "From e-crm to s-crm. Critical factors underpinning the social crm activities of smes," Small Enterprise Research, vol. 21, no. 1, pp. 99-116, 2014.

[49] C. B. Dobni, "Measuring innovation culture in organizations: the development of a generalized innovation culture construct using exploratory factor analysis," European Journal of Innovation Management, vol. 11, no. 4, pp. 539-559, 2008.

[50] R. L. Gorsuch, "Exploratory factor analysis: its role in item analysis," Journal of Personality Assessment, vol. 68, no. 3, pp. 532-560, 1997.

[51] T. R. Hinkin, "A brief tutorial on the development of measures for use in survey questionnaires," Organizational Research Methods, vol. 1, no. 1, pp. 104-121, 1998.

[52] L. J. Cronbach, "Coefficient alpha and the internal structure of tests," Psychometrika, vol. 16, no. 3, pp. 297-334, 1951.

[53] H. F. Kaiser, "An index of factorial simplicity," Psychometrika, vol. 39, no. 1, pp. 31-36, 1974.

[54] C. Fornell and D. F. Larcker, "Evaluating structural equation models with unobservable variables and measurement error," Journal of Marketing Research, vol. 18, no. 1, pp. 39-50, 1981.

[55] S. W. O'Leary-Kelly and R. J. Vokurka, "The empirical assessment of construct validity," Journal of Operations Management, vol. 16, no. 4, pp. 387-405, 1998.

[56] J. C. Anderson and D. W. Gerbing, "Structural equation modeling in practice: a review and recommended two-step approach," Psychological Bulletin, vol. 103, no. 3, pp. 411-423, 1988.

[57] W. W. Chin, “The partial least squares approach to structural equation modeling," in Modern Methods for Business Research, G. A. Marcoulides, Ed., pp. 295-358, Lawrence Erlbaum, Mahwah, NJ, USA, 1998.

[58] M. Haenlein and A. M. Kaplan, "A beginner's guide to partial least squares analysis," Understanding Statistics, vol. 3, no. 4, pp. 283-297, 2004.

[59] G. R. Hancock and M. J. Freeman, "Power and sample size for the root mean square error of approximation test of not close fit in structural equation modeling," Educational and Psychological Measurement, vol. 61, no. 5, pp. 741-758, 2001.

[60] V. Ramaswamy, “Co-creating value through customers' experiences: the Nike case," Strategy and Leadership, vol. 36, no. 5, pp. 9-14, 2008.

[61] B. Bowonder, A. Dambal, S. Kumar, and A. Shirodkar, "Innovation strategies for creating competitive advantage," Research Technology Management, vol. 53, no. 3, pp. 19-32, 2010.

[62] T. D. Little, N. A. Card, J. A. Bovaird, K. J. Preacher, and C. S. Crandall, "Structural equation modeling of mediation and 
moderation with contextual factors," in Modeling Contextual Effects in Longitudinal Studies, pp. 207-230, Erlbaum, Mahwah, NJ, USA, 2007.

[63] R. M. Baron and D. A. Kenny, "The moderator-mediator variable distinction in social psychological research: conceptual, strategic, and statistical considerations," Journal of Personality and Social Psychology, vol. 51, no. 6, pp. 1173-1182, 1986. 


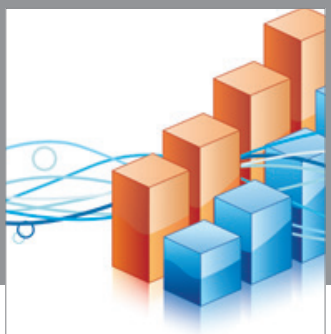

Advances in

Operations Research

vatem alat4

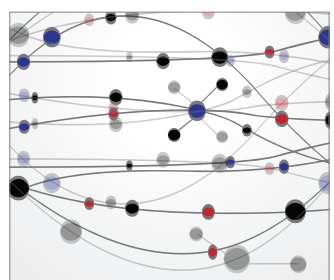

\section{The Scientific} World Journal
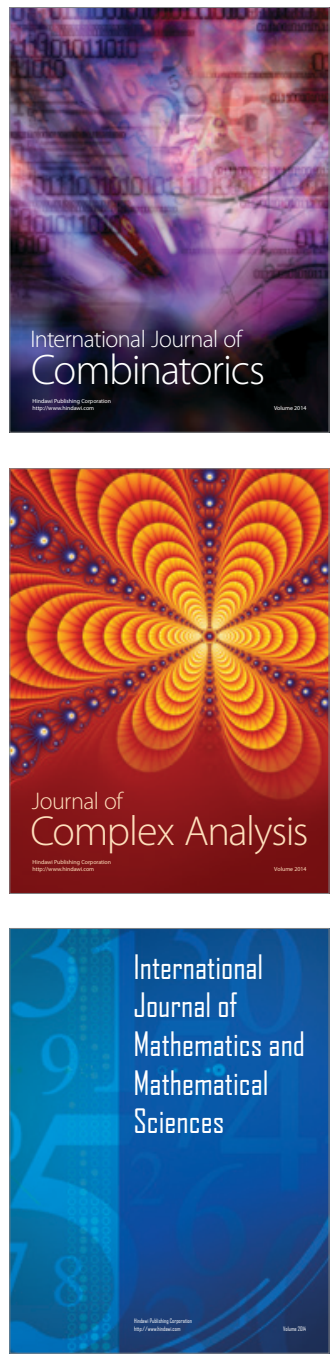
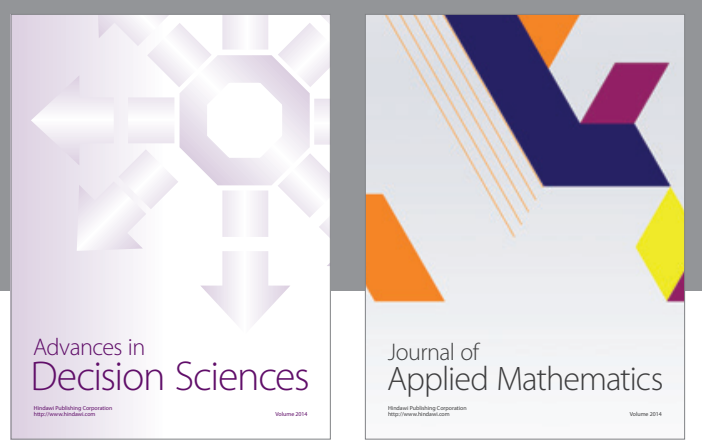

Algebra

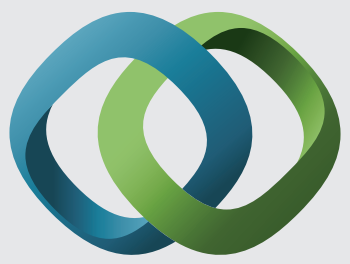

\section{Hindawi}

Submit your manuscripts at

https://www.hindawi.com
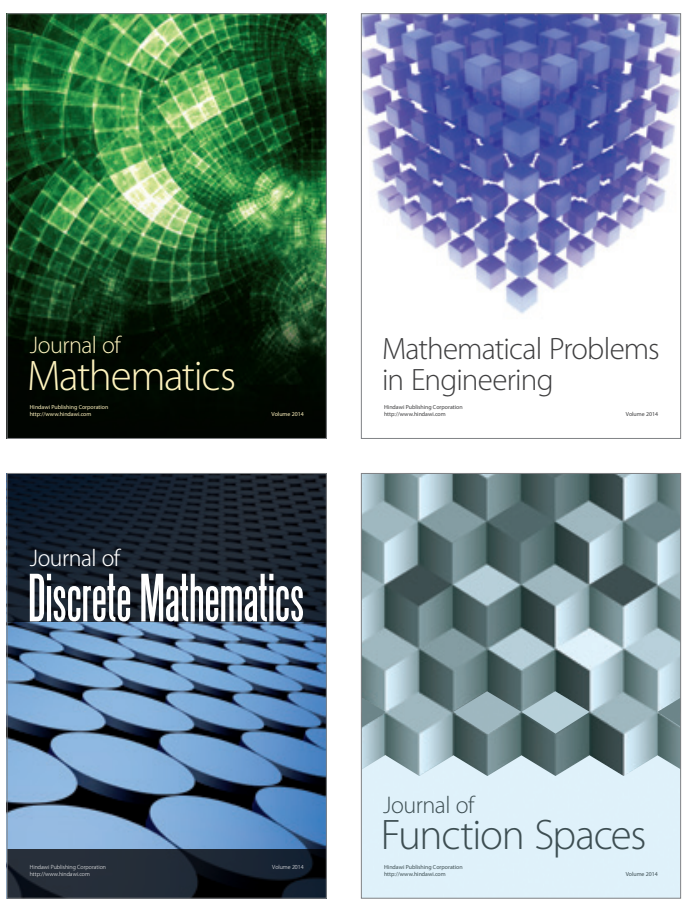

Mathematical Problems in Engineering
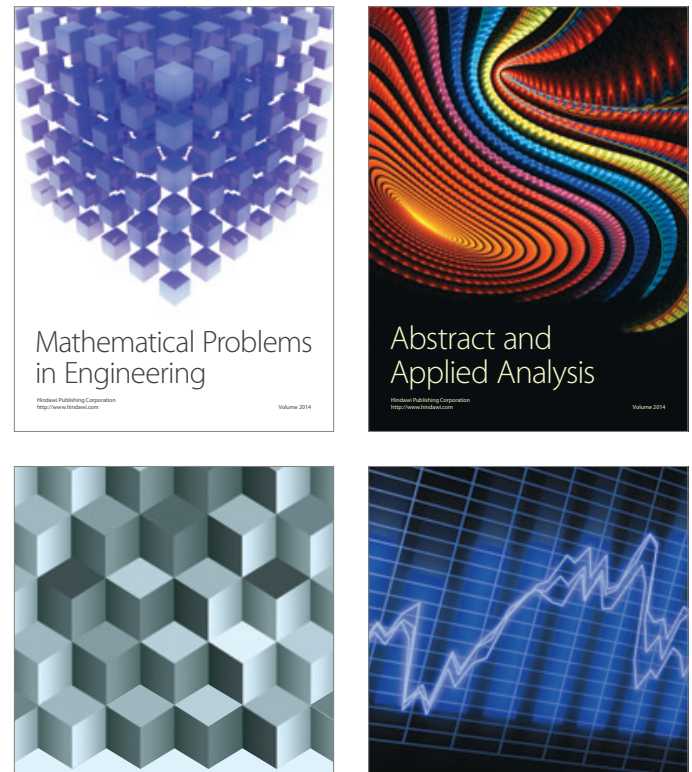

Journal of

Function Spaces

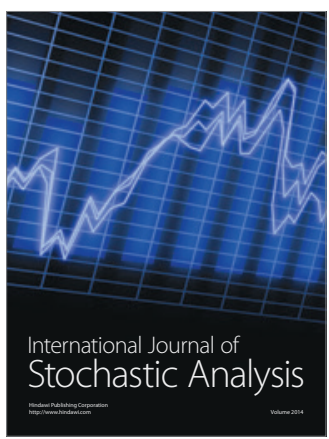

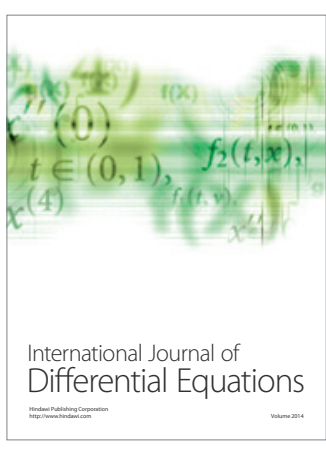
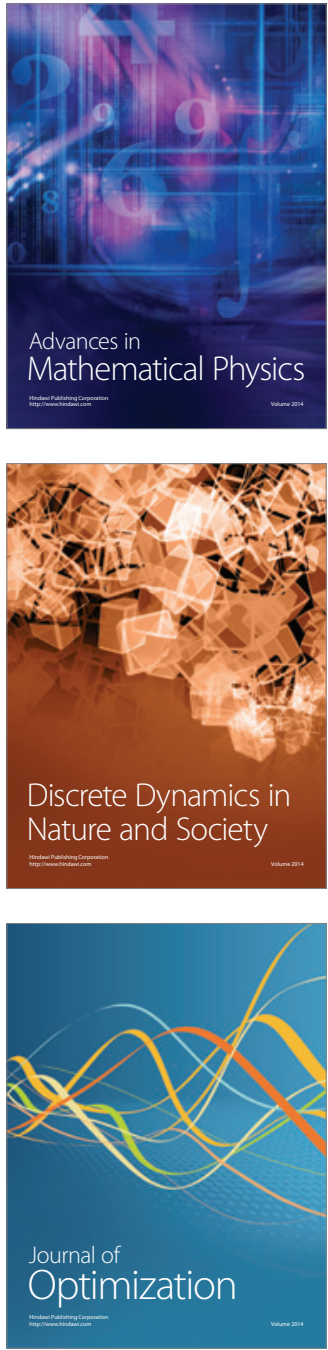